\title{
Effect of cowpea enrichment on the physico-chemical, mineral and microbiological properties of maize:cowpea flour blends
}

\author{
Shakpo, I. O. ${ }^{1,2 *}$ and Osundahunsi, O. F. ${ }^{2}$ \\ ${ }^{1}$ Food Science and Technology Department, Rufus Giwa Polytechnic, Owo, Nigeria. \\ ${ }^{2}$ Food Science and Technology Department, Federal University of Technology, Akure, Nigeria. \\ *Corresponding author. Email: de.kings.io@gmail.com. Tel: +2348036267170.
}

Copyright (@) 2016 Shakpo and Osundahunsi. This article remains permanently open access under the terms of the Creative Commons Attribution License 4.0, which permits unrestricted use, distribution, and reproduction in any medium, provided the original work is properly cited.

Received 25th February, 2016; Accepted 20th June, 2016

\begin{abstract}
Production of nutritious low cost complementary foods is a panacea to malnutrition in developing countries. The objective of this study was to examine the complementary effect of cowpea on some quality attributes of maize flour. Flour blends were produced from maize and cowpea flours in the following ratios of maize: cowpea; 90:10, $80: 20,70: 30$ and 100\% maize as control. Physicochemical (proximate, mineral and functional properties) and microbiological analyses were carried out on the flour blends The proximate result showed that the protein content ranged from 8.85 to $10.52 \%$, total ash, 1.55 to $1.93 \%$; fat content, 10.50 to $11.96 \%$; moisture content, 5.05 to $5.77 \%$ and fibre content, 9.88 to $14.43 \%$. The blend with 30\% cowpea substitution gave the highest value. It was observed that fat content was not affected by cowpea substitution. Mineral determination showed that potassium, sodium, zinc, and iron contents increased with cowpea substitution in the blends, with 30\% cowpea substitution having the highest values. Calcium contents were $3.34,3.36,3.39 \mathrm{mg} / \mathrm{kg}$ for $10 \%, 20 \%$ and $30 \%$ cowpea substitution respectively; while calcium was not detected in $100 \%$ maize. Functional properties evaluated showed that bulk density ranged from 0.72 to $0.81 \mathrm{~g} / \mathrm{ml}$, swelling index, 0.66 to $1.03 \mathrm{ml} / \mathrm{g}$, least gelation, 2.10 to $6.11 \%$, foaming, 7.67 to $15.36 \%$, water absorption, 2.41 to $3.23 \%$, oil absorption 1.24 to $1.45 \%$, emulsion capacity, 8.76 to $37.15 \%$ and emulsion stability 7.43 to $14.13 \%$. Microbiological evaluation for the flour blends showed that total viable count ranged from 3.80 to $4.7 \times 10^{3} \mathrm{Cfu} / \mathrm{ml}$, while yeast and mould count ranged from 2.2 to $3.17 \times 10^{3} \mathrm{Sfu} / \mathrm{ml}$ for blends. The overall result showed that $20 \%$ cowpea substitution is the most adequate percentage to produce an acceptable and nutritious flour blend from maize and cowpea which can be useful for pastries and confectioneries.
\end{abstract}

Keywords: Cowpea, enrichment, maize, malnutrition, physico-chemical.

\section{INTRODUCTION}

The world cultivated cereals include wheat, maize, rice, barley, Oat, rye, sorghum, millet etc., an important characteristic of cereals is that they have high carbohydrate, low fat and a fair content of protein (Olugbani et al., 2002). Wheat is a popular cereal grain that has been used for the production of many snacks, such as chin-chin, biscuit, pie, bread and other pastry products (David, 2006) but the tropical climate of many developing countries does not encourage commercial wheat cultivation, leading to reliance on wheat importation. Recently in Nigeria, all effort is geared towards promoting indigenous crop, thereby reducing total reliance on imported foods. In developing countries, where malnutrition remains a major health problem in infants and pre-school children, considerable efforts to improve the health and nutritional status of growing children have focused on the production of nutritious lowcost complementary foods (Osundahunsi and Aworh, 2003).

Maize (Zea mays) is a cereal crop widely cultivated in Nigeria and the tropics. It is used in the production of various food items such as "Ogi (AkamulAgidl" (fermen- 
ted maize food), custard, "epiti, (Barber et al., 2010) or Elekute ogede" (a steamed maize-plantain pudding), "aadun (a roasted maize flour mixed with palm oil) "kokoro" (a deep fried maize paste seasoned with salt and sugar) (Chikwendu, 2007) "Abari" also a steamed maize pudding similar to moin-moin and "Ipekere or Ipakere agbado" (a deep-fried maize paste seasoned with pepper, salt and onion). Maize is sometimes used as the starch source for beer (Maize encyclopedia, 2013). According to FAO (1992), the protein content of maize ranges from 8 to $11 \%$, a variety of snack foods widely consumed by Nigerians are made of low-protein cereals with lysine and tryptophan as limiting amino acids (Omueti et al., 1992) that are essential for human nutrition.

Cowpeas (Vigna unguiculata) are an important source of protein in developing countries especially in Nigeria. It is an example of grain legume which has found utilization in various ways in traditional and modern food processing in the world (Odedeji and Oyeleke, 2011). In countries such as Nigeria, and most of the sub-Sahara countries, animal products representing high concentration and quality of protein are either too expensive or simply unaffordable, thus increasing the dependence on cereal grains, roots and tuber crops (Ihekoronye and Ngoddy, 1985). In Nigeria, cowpea is consumed in the form of bean pudding, bean cake, baked bean, fried bean, and bean soup amongst others (Odedeji and Oyeleke, 2011). According to IITA (2009), cowpea grain contains about 25 $\%$ protein, and several vitamins and minerals. Most tropical countries are faced with Protein-Energy Malnutrition (PEM) as a result of increasing population and enhanced dependence on cereal and tuber based diet. It is estimated that about 800 million malnourished people exist in some of the least developed countries, mostly in sub-Sahara Africa (FAO, 2010; Meyers et al., 1997). Cereal and legume are known to complement each other when consumed together so as to provide adequate nutrients for the improvement of the nutritional well-being of the people (Chikwendu, 2007). Cowpea and maize, in spite of their great nutritional and economic importance are highly susceptible to many diseases and pests right from growing stage up to storage (Singh et al., 1997) and final consumption. Therefore, there is need to reduce post-harvest losses of these valuable grains via processing them into flour. There is limited information on the nutrient composition of cereal flour enriched with cowpea, hence, the need to go into such research.

\section{MATERIALS AND METHODS}

\section{Materials}

Dried yellow maize (Zea mays), cowpea (Vigna unguiculata) and other ingredients (onion, fresh pepper, palm oil) used for this research were sourced from Obada market in Emure-ile, Owo Local Government Area of Ondo State, Nigeria. While the AAS (Model 210 VGP Buck Atomic Absorption Spectrophotometre) and flame photometre used for mineral determination were from the Chemistry Laboratory of Science Laboratory Technology department, Hot air oven (Model Memmert 854, Gallenkamp, UK), water bath (Model HH - 6), Kenwood mixer (Model A 907 D, Kenwood Ltd, England) and other equipment used for this research were from the Food Chemistry Laboratory of the Department of Food Science and Technology, Rufus Giwa Polytechnic, Owo, Ondo State. All chemicals used for the analyses were of analytical grade.

\section{Methods}

\section{Production of maize flour}

Maize flour was produced following the procedure adopted by Barber et al., (2010) with slight modification. The maize grains were sorted to remove extraneous matter, then washed with potable water and boiled for $1 \mathrm{~h}$ in a pressure pot. The drying was achieved with the aid of hot air oven at $65^{\circ} \mathrm{C}$ for $8 \mathrm{~h}$. The dried maize was milled into flour using attrition mill and was stored in air tight container until needed for further analysis.

\section{Production of Cowpea flour}

Matured and dried cowpea seeds were carefully cleaned, sorted to remove defective ones, stones and other extraneous matters. The cleaned seeds were soaked in potable water for just 20 min to soften the seed coat for easy dehulling. The dehulled cowpea was dried in hot air oven at $65^{\circ} \mathrm{C}$ for $24 \mathrm{~h}$ and milled into flour. The flour was stored in air-tight polythene until needed.

\section{Formulation}

The maize:cowpea flour blends were formulated into four ratios: 70:30; 80:20; 90:10 and 100:0 respectively, these were kept in air tight container until needed to be used (for analysis and thereafter production of fortified maize snack).

\section{Analyses}

Determination of the proximate composition of the flour blends (AOAC, 1990)

Proximate parameters including moisture, crude fat, crude fibre, crude protein and ash contents were all 
determined using the above standard method.

\section{Determination of carbohydrate by difference}

This is the summation of the result obtained from fat, crude fibre, ash and protein contents determination, all subtracted from 100 .

$$
\begin{aligned}
\% \mathrm{CHO} \text { content }= & 100-(\text { Protein }+ \text { Ash }+ \text { Moisture } \\
& + \text { Crude fibre }+ \text { fat })
\end{aligned}
$$

\section{Functional properties}

\section{Determination of bulk density}

The bulk density (BD) was determined according to the method described by Okaka and Potter (1977). A $50 \mathrm{~g}$ sample was placed into a $100 \mathrm{ml}$ graduated cylinder. The cylinder was tapped on the palm for 40 to 50 times and the bulk density was determined by reading the final volume. Bulk density was calculated as:

$$
\mathrm{BD}=\frac{\text { Mass of materials }}{\text { volume of material after tapping }}
$$

\section{Determination of foaming capacity}

The method of Coffman and Garcia (1977) was employed in the determination of foaming capacity. Sample $(1 \mathrm{~g})$ was whipped with $50 \mathrm{ml}$ distilled water for $5 \mathrm{~min}$ in a Kenwood blender at speed set at maximum and was poured into a $100 \mathrm{ml}$ graduated cylinder. Total volume at time interval of $0,5 \mathrm{~min}, 10 \mathrm{~min}$ up to 1 hour was noted to study the foaming capacity.

$\%$ Volume increase

$$
=\frac{\text { Vol. after whipping }- \text { Vol. before whipping }}{\text { volume before whipping }} \times \frac{100}{1}
$$

\section{Determination of least gelation}

The modified procedure of Coffman and Garcia (1977) was used to determine gelation properties. Appropriate sample suspensions were prepared in $5 \mathrm{ml}$ of distilled water each to make $2-20 \%(\mathrm{w} / \mathrm{v})$ suspension. The test tubes containing these suspensions were heated for $1 \mathrm{~h}$ in boiling water (bath) followed by rapid cooling under running tap water. The test tubes were then cooled for 1 $\mathrm{h}$. The least gelation concentration was determined as concentration when the sample from the inverted test tube did not fall down or slip.

$\%$ Least gelation $=\frac{\text { weight of sample }}{5(\mathrm{ml}) \text { of water }} \times \frac{100}{1}$

\section{Determination of water and oil absorption capacities}

Water absorption capacities (WAC) of the samples were determined by a combination of the AACC (2000) and Sathe et al., (1982) methods. Sample $(1.0 \mathrm{~g})$ was dispersed in $10 \mathrm{ml}$ of distilled water. The content was mixed for $5 \mathrm{~min}$ on a magnetic stirrer or using glass rod. The mixture was centrifuged at $3,500 \mathrm{rpm}$ for $30 \mathrm{~min}$ and the volume of the supernatant left after centrifuging was noted. Water bound was calculated from the difference in volume of the initial volume of the water used and the final volume after centrifuging. The same procedure was used for oil absorption capacity (OAC), just that oil was used in place of water.

$$
\begin{aligned}
& \text { WAC }=\frac{\text { Volume of water absorbed }}{\text { weight of sample }} \times \frac{100}{1} \\
& \text { OAC }=\frac{\text { Volume of oil absorbed }}{\text { weight of sample }} \times \frac{100}{1}
\end{aligned}
$$

\section{Determination of emulsion capacity and stability}

The emulsion capacity (EC) and stability (ES) were determined by the method of Masumateu (1972). The emulsion, $20 \mathrm{~g}$ sample, $20 \mathrm{ml}$ distilled water and $20 \mathrm{ml}$ soybean oil was prepared in a calibrated centrifuge tube. The emulsion was centrifuged at $3,500 \mathrm{rpm}$ for $5 \mathrm{~min}$. The ratio of the height of the emulsion layer to the total height of the mixture was calculated as the emulsion activity expressed in percentage. The emulsion stability was estimated after heating the emulsion contained in a calibrated centrifuge tube at $80^{\circ} \mathrm{C}$ for $30 \mathrm{~min}$ in a water bath, cooled for 15 min under running tap water and centrifuged at $2000 \mathrm{rpm}$ for $15 \mathrm{~min}$. The emulsion stability expressed as a percentage was calculated as the ratio of the height of the emulsified layer to the total height of the mixture.

$$
\begin{aligned}
& \mathrm{EC}=\frac{\text { height } \text { of the emulsion layer }}{\text { total height of the misture }} \times \frac{100}{1} \\
& \mathrm{ES}=\frac{\text { height of the emulsion layer }}{\text { total height of the misture after heating }} \times \frac{100}{1}
\end{aligned}
$$

\section{Determination of swelling index}

The swelling index was determined using the method of Ukpabi and Ndimele (1990). Twenty five grams of each sample were weighed into a $210 \mathrm{ml}$ measuring cylinder; $150 \mathrm{ml}$ of distilled water were added and allowed to stand for $4 \mathrm{~h}$ and the level of swelling was observed thereafter.

$$
\begin{aligned}
& \text { Swelling index } \\
& =\frac{\text { Volume after soaking }- \text { Volume before soaking }}{\text { weight of sample }} \times \frac{100}{1}
\end{aligned}
$$


Table 1. Proximate Composition of the Flour Blends (Dry Weight Basis).

\begin{tabular}{lcccccc}
\hline Samples & M.C(\%) & Ash(\%) & Fat(\%) & Fibre(\%) & Protein(\%) & Carbohydrate(\%) \\
\hline WMF & $2.67 \pm 0.15^{\mathrm{c}}$ & $0.96 \pm 0.04^{\mathrm{d}}$ & $10.14 \pm 0.03^{\mathrm{b}}$ & $9.55 \pm 0.03^{\mathrm{d}}$ & $7.26 \pm 0.28^{\mathrm{d}}$ & $69.42 \pm 0.42^{\mathrm{a}}$ \\
MC9 & $5.05 \pm 0.05^{\mathrm{b}}$ & $1.55 \pm 0.02^{\mathrm{c}}$ & $10.50 \pm 0.07^{\mathrm{a}}$ & $9.88 \pm 0.20^{\mathrm{c}}$ & $8.85 \pm 0.04^{\mathrm{c}}$ & $64.15 \pm 0.31^{\mathrm{b}}$ \\
MC8 & $5.07 \pm 0.03^{\mathrm{b}}$ & $1.65 \pm 0.02^{\mathrm{b}}$ & $11.95 \pm 0.03^{\mathrm{a}}$ & $10.98 \pm 0.07^{\mathrm{b}}$ & $10.08 \pm 0.34^{\mathrm{b}}$ & $60.27 \pm 0.39^{\mathrm{c}}$ \\
MC7 & $5.77 \pm 1.23^{\mathrm{a}}$ & $1.93 \pm 0.02^{\mathrm{a}}$ & $11.96 \pm 0.03^{\mathrm{a}}$ & $14.43 \pm 0.25^{\mathrm{a}}$ & $10.52 \pm 0.03^{\mathrm{a}}$ & $55.39 \pm 0.16^{\mathrm{d}}$ \\
\hline
\end{tabular}

Values with the same superscript in the column are not significantly different $(p \leq 0.05)$. MC, moisture content, WMF, 100\% maize - control, MC9, $10 \%$ cowpea; $90 \%$ maize, MC8, 20\%cowpea; $80 \%$ maize, MC7, 30\% cowpea; $70 \%$ maize. Letters a-d show the degree of significant difference.

\section{Determination of mineral content}

The mineral contents of the samples were determined after acid digestion of the ashed samples as follows: $2 \mathrm{ml}$ of aqua regia (mixture of $\mathrm{HCl}$ and $\mathrm{HNO}_{3}$ in ratio $3: 1$ ) was added to each ashed sample in a100 ml flask and made up to the mark with distilled water. The solution was then filtered through N0.4 Whatman filter paper and the clear solution was kept in a plastic bottle with lid. Calcium, Zinc and Iron were determined using Atomic Absorption Spectrophotometre while sodium and potassium were determined using flame photometre.

\section{Microbiological analysis}

The media used for microbiological analysis include Nutrient agar (NA), Eosine Methylene Blue (EMB) and Potato Dextrose Agar (PDA) for total viable count, coliform test, yeast and mould count respectively. These media were obtained from the Microbiology Laboratory of the Department of Food Science and Technology, Rufus Giwa Polytechnic, Owo and were prepared according to the manufacturer's instruction. The procedure described by Collins et al. (1989) as reported by Otunola et al. (2012) was used to evaluate the microbiological characteristics of the samples. The sample $(10 \mathrm{~g})$ was added to $100 \mathrm{ml}$ of distilled water and mixed thoroughly after which $1 \mathrm{ml}$ of the mixture was serially diluted for estimating the number of microorganisms.

\section{Statistical analysis}

The SPSS for windows programme version 15.0 was used to analyse the results obtained: means and standard deviation of all the samples were calculated and compared. The results obtained were in triplicate and subjected to analysis of variance ANOVA and the means were separated by New Duncan Multiple Range Test (NDMRT).

\section{RESULTS}

\section{Proximate Composition of Flour Blends}

The result of the proximate composition of the flour blends showed that there were significant differences $(p \leq 0.05)$ among the samples examined. The values obtained for ash ranged from 0.96 to $1.93 \%$, fat 10.14 to $11.96 \%$, fibre 9.55 to $14.43 \%$ and protein 7.26 to $10.52 \%$ contents also increased with increase in the cowpea substitution (Table 1). The least values were obtained in each sample for the $100 \%$ maize flour followed by $10 \%$ cowpea substitution in that order and the highest value recorded for $30 \%$ cowpea substitution. The ash content of the $100 \%$ maize flour $(0.96 \%)$ was significantly different from those of the flour blends $(1.55 \%, 1.65 \%$, $1.93 \%$ ) for $10 \%, 20 \%$ and $30 \%$ cowpea inclusion respectively. The fat content obtained for the flour blends (10.50\%, $11.95 \%$ and $11.96 \%$ for samples $10 \%, 20 \%$, and $30 \%$ cowpea substitution respectively) were not significantly different among the flour blends but these values were significantly different from the fat content value obtained for the $100 \%$ maize flour (Table 1 ). There were also significant differences $(p \leq 0.05)$ among the values obtained for fibre and protein contents. While moisture, ash, fat, fibre and protein contents increased with increasing cowpea substitution, there was reduction in the carbohydrate content as the cowpea inclusion increases, and these values $(69.42 \%, 64.15 \%, 60.27 \%$, $55.39 \%$ for $100 \%$ maize flour, $10 \%, 20 \%$ and $30 \%$ cowpea substitution respectively) were also significantly different $(p \leq 0.05)$ among the samples.

\section{Functional Properties of Maize and Cowpea Flour Blends}

The functional properties of the flour blends showed that there were significant differences in the functional properties of the samples examined. The bulk density ranged from $0.72 \mathrm{~g} / \mathrm{ml}$ to $0.81 \mathrm{~g} / \mathrm{ml}$ with lowest and highest values recorded for $100 \%$ maize, $10 \%$ and $30 \%$ cowpea substitution respectively (Table 2). However, there was no significant difference $(p \leq 0.05)$ between the bulk densities of the samples with $10 \%$ and $30 \%$ cowpea substitution respectively. The values obtained for foaming capacity ranged from 7.67 to $11.54 \%$ with the highest value recorded for the sample with $20 \%$ cowpea substitution and the lowest value recorded for $100 \%$ maize flour. This result showed that cowpea substitution increased the foaming capacity of the flour blends, but 
Table 2. Functional Properties of the Flour Blends.

\begin{tabular}{lcccccccc}
\hline Samples & $\mathbf{B} / \mathbf{D}(\mathbf{g} / \mathbf{m l})$ & $\mathbf{F C}(\%)$ & $\mathbf{W A C}(\%)$ & $\mathbf{O A C}(\%)$ & $\mathbf{L G}(\%)$ & $\mathbf{S W I}(\mathbf{m l} / \mathbf{g})$ & $\mathbf{E C}(\%)$ & $\mathbf{E S}(\%)$ \\
\hline WMF & $0.72 \pm 0.01^{\mathrm{c}}$ & $7.67 \pm 0.02^{\mathrm{c}}$ & $2.41 \pm 0.02^{\mathrm{a}}$ & $1.24 \pm 0.02^{\mathrm{c}}$ & $6.11 \pm 0.11^{\mathrm{a}}$ & $1.03 \pm 0.03^{\mathrm{a}}$ & $8.76 \pm 0.02^{\mathrm{d}}$ & $7.43 \pm 0.02^{\mathrm{d}}$ \\
MC9 & $0.81 \pm 0.02^{\mathrm{b}}$ & $11.54 \pm 0.02^{\mathrm{b}}$ & $3.22 \pm 0.02^{\mathrm{b}}$ & $1.32 \pm 0.03^{\mathrm{b}}$ & $4.10 \pm 0.01^{\mathrm{b}}$ & $0.97 \pm 0.01^{\mathrm{b}}$ & $28.15 \pm 0.17^{\mathrm{c}}$ & $12.15 \pm 0.05^{\mathrm{c}}$ \\
MC8 & $0.76 \pm 0.02^{\mathrm{b}}$ & $15.36 \pm 0.03^{\mathrm{a}}$ & $3.23 \pm 0.02^{\mathrm{b}}$ & $1.32 \pm 0.03^{\mathrm{b}}$ & $4.06 \pm 0.05^{\mathrm{b}}$ & $0.74 \pm 0.03^{\mathrm{c}}$ & $35.08 \pm 0.07^{\mathrm{b}}$ & $13.16 \pm 0.17^{\mathrm{b}}$ \\
MC7 & $0.81 \pm 0.01^{\mathrm{a}}$ & $11.53 \pm 0.03^{\mathrm{b}}$ & $3.23 \pm 0.01^{\mathrm{b}}$ & $1.45 \pm 0.01^{\mathrm{a}}$ & $2.10 \pm 0.1^{\mathrm{c}}$ & $0.66 \pm 0.02^{\mathrm{d}}$ & $37.15 \pm 0.16^{\mathrm{a}}$ & $14.13 \pm 0.02^{\mathrm{a}}$ \\
\hline
\end{tabular}

Values with the same superscript in the column are not significantly different $(p \leq 0.05)$. B/D, bulk density, FC, foaming capacity, WAC, water absorption capacity, OAC, oil absorption capacity, LG, Least gelation, SWI, swelling index, EC, emulsion capacity, ES, emulsion stability, Letters a-d show the degree of significant difference.

Table 3. Mineral Composition of the Flour Blends

\begin{tabular}{lccccc}
\hline Samples & $\mathbf{K}(\mathbf{g} / \mathbf{k g})$ & $\mathbf{N a}(\mathbf{g} / \mathbf{k g})$ & $\mathbf{C a}(\mathbf{m g} / \mathbf{k g})$ & $\mathbf{Z n}(\mathbf{m g} / \mathbf{k g})$ & Iron $(\mathbf{m g} / \mathbf{k g})$ \\
\hline WMF & $0.43 \pm 0.01^{\mathrm{c}}$ & $0.37 \pm 0.02^{\mathrm{c}}$ & $\mathrm{ND}$ & $0.46 \pm 0.03^{\mathrm{d}}$ & $0.88 \pm 0.02^{\mathrm{b}}$ \\
MC9 & $0.72 \pm 0.02^{\mathrm{b}}$ & $0.37 \pm 0.01^{\mathrm{c}}$ & $3.34 \pm 0.01^{\mathrm{a}}$ & $0.77 \pm 0.20^{\mathrm{c}}$ & $0.94 \pm 0.02^{\mathrm{d}}$ \\
MC8 & $0.89 \pm 0.01^{\mathrm{a}}$ & $0.39 \pm 0.20^{\mathrm{b}}$ & $3.36 \pm 0.02^{\mathrm{a}}$ & $10.98 \pm 0.07^{\mathrm{b}}$ & $1.17 \pm 0.02^{\mathrm{c}}$ \\
MC7 & $0.92 \pm 0.02^{\mathrm{a}}$ & $0.43 \pm 0.02^{\mathrm{a}}$ & $3.39 \pm 0.03^{\mathrm{a}}$ & $1.13 \pm 0.02^{\mathrm{a}}$ & $1.43 \pm 0.01^{\mathrm{a}}$ \\
\hline
\end{tabular}

Values with the same superscript in the column are not significantly different $(p \leq 0.05)$. K, potassium, $\mathbf{N a}$, sodium, Ca, calcium, $\mathbf{Z n}$, zinc. Letters a-d show the degree of significant difference.

the reverse was the case for water absorption capacity as this decreased with increasing cowpea substitution though with slight difference. The water absorption capacity of $100 \%$ maize flour was $2.41 \%$ which was slightly higher than the values obtained for the flour blends $(3.22 \%$ and $3.23 \%)$, there was no significant difference $(p \leq 0.05)$ in water absorption capacity among the flour blends (Table 2). The oil absorption capacities (OAC) of the samples also differ slightly but increased with cowpea inclusion with the highest value (1.45\%) recorded for the sample with 30\% cowpea substitution while the lowest value (1.24\%) was recorded for $100 \%$ maize flour. The least gelation of the flour blends ranged from 6.11 to $2.1 \%$, sample with $30 \%$ cowpea substitution had the lowest value and $100 \%$ maize had highest. These results showed that the increased in cowpea addition affect the least gelation of the flour blends by increasing the thickness of the gel. The swelling index of the flour blends was between $1.03 \mathrm{ml} / \mathrm{g}$ to $0.66 \mathrm{ml} / \mathrm{g}$ with $100 \%$ maize having the highest value and sample with $30 \%$ cowpea substitution having the least; this showed that addition of cowpea significantly reduced the swelling capacity of the flour blends. Emulsion capacity and stability were greatly influenced by the addition of cowpea in the flour blends as increase in cowpea increased the emulsion capacity and stability of the flour blends respectively. The values obtained for emulsion capacity and stability ranged from 8.76 to $37.15 \%$ and 7.43 to $14.13 \%$ for $100 \%$ maize having the lowest and $30 \%$ cowpea substitution having the highest value respectively (Table 2). These showed that emulsion capacity and stability are significantly increased with increase in cowpea addition.

\section{Mineral Composition of Maize and Cowpea Flour Blends}

The result of the mineral composition of the flour blends revealed significant differences $(p<0.05)$ between the control sample (100\% maize) and the flour blends. The values obtained for potassium were $4.3 \mathrm{~g} / 100 \mathrm{~g}, 7.2$ $\mathrm{g} / 100 \mathrm{~g}, 8.9 \mathrm{~g} / 100 \mathrm{~g}$ and $9.2 \mathrm{~g} / 100 \mathrm{~g}$ for $100 \%$ maize, $10 \%, 20 \%, 30 \%$ cowpea substitution respectively (Table $3)$. These results showed that cowpea addition increased the potassium content of the sample. The same trend was observed for sodium, zinc and iron with values ranging from 3.7 to $4.3 \mathrm{~g} / 100 \mathrm{~g}, 0.46$ to $1.13 \mathrm{mg} / \mathrm{kg}$, and 0.88 to $1.43 \mathrm{mg} / \mathrm{kg}$ respectively. While calcium was not detected in the control sample $(100 \%$ maize), the result obtained indicated that there was no significant difference $(p \leq 0.05)$ in the calcium content among the flour blends. Addition of cowpea into maize was observed to increase the mineral contents of the flour blends.

\section{Microbiological Qualities of the Flour Blends}

The microbiological status of the flour blends showed that the total viable count ranged from 3.8 to $4.7 \times 10^{3} \mathrm{cfu} / \mathrm{ml}$ with the highest value recorded for $100 \%$ maize flour and the lowest value recorded for $10 \%$ cowpea substitution, with exception of this sample, there was no significant difference $(p \leq 0.05)$ in the total viable count of the control sample and the flour blends (Table 4). However, significant difference was observed in the result obtained for the yeast and mould count which ranged between 2.2 to $3.17 \times 10^{3} \mathrm{sfu} / \mathrm{ml}$, the least value was recorded for 
Table 4. Microbiological Status of the Flour Blends.

\begin{tabular}{|c|c|c|c|}
\hline Samples & TVC( $\left.\times 10^{3} \mathrm{Cfu} / \mathrm{ml}\right)$ & YMC(x $\left.10^{3} \mathrm{Sfu} / \mathrm{ml}\right)$ & Coliform (x 10 $\left.{ }^{3} \mathrm{Cfu} / \mathrm{ml}\right)$ \\
\hline WMF & $4.7 \pm 0.17^{a}$ & $2.2 \pm 0.12^{d}$ & $\mathrm{~N} / \mathrm{A}$ \\
\hline MC9 & $3.8 \pm 0.21^{b}$ & $2.6 \pm 0.10^{b}$ & $\mathrm{~N} / \mathrm{A}$ \\
\hline MC8 & $4.5 \pm 0.12^{a}$ & $2.3 \pm 0.12^{\mathrm{c}}$ & $\mathrm{N} / \mathrm{A}$ \\
\hline MC7 & $4.3 \pm 0.10^{\mathrm{a}}$ & $3.17 \pm 0.15^{a}$ & $\mathrm{~N} / \mathrm{A}$ \\
\hline
\end{tabular}

Values with the same superscript in the column are not significantly different $(p<0.05)$. TVC, Total viable count, YMC, Yeast and Mould count, N/A, Not Available, WMF, 100\% maize, MC9, 10\% cowpea substitution, MC8, 20\% cowpea substitution, MC7, 30\% cowpea substitution.

$100 \%$ Maize flour while the sample with $30 \%$ cowpea substitution has the highest. The samples showed no growth for coliform test.

\section{DISCUSSION}

Several data trends were observed in the result of the proximate composition of the flour blends. The moisture content of the flour blends was much higher than the value obtained for $100 \%$ maize flour. The sample with $10 \%$ cowpea substitution has the least value while the sample with $30 \%$ cowpea substitution has the highest moisture content, the values were observed to increase with increase in cowpea enrichment which implies that cowpea substitution enhanced water absorption in the sample. Similar observation was made by Barber et al. (2010). Protein content increased as a result of cowpea substitution in the flour blends, the values were significantly different among the samples. The values of fat content obtained for the flour blends were not significantly different among the flour blends but these values were significantly different $(p \leq 0.05)$ from the fat content value obtained for the $100 \%$ maize flour. There were also significant differences among the values obtained for ash and fibre contents. While moisture, ash, fat, fibre and protein contents increased with the increase in the cowpea fortification, there was reduction in the carbohydrate content as the cowpea inclusion increases, and these values were also significantly different $(p \leq 0.05)$ among the samples. Similar trend was also reported by Etsey et al. (2007).

The results of the functional properties of the flour blends showed that the cowpea substitution increased the water and oil absorption capacities as well as foaming capacity, emulsion capacity and stability. This agrees with the report of Barber et al. (2010) in the study of "effect of cowpea supplementation on the physicochemical and sensory characteristics of epiti - a steamed maize/plantain pudding. The result for water absorption capacity agrees with the report of Afoakwa (1996) who reported that, in flour, proteins are mainly responsible for water uptake and to a lesser extent starch and cellulose at room temperature; the research of Sefa-Dedeh et al.
(2001) also concurred with this. The value for oil absorption capacity increased with increase in cowpea substitution but these are lower than the water absorption capacities. The values for oil absorption capacities compared to water absorption capacities suggest that the major proteins in the flours are predominantly hydrophilic (Deshpande et al., 1983). There was a significant difference in the foaming capacities. The values obtained for the least gelation, bulk density and swelling index also showed significant difference. The emulsion capacity and stability also increased with increase in cowpea substitution respectively. These showed that emulsion capacity and stability are significantly increased with increase in cowpea addition.

There was a significant difference $(p \leq 0.05)$ between the control sample (100\% maize) and the flour blends in terms of mineral. The values obtained for potassium in the samples was promising. These results showed that cowpea addition increases the potassium content of the sample. The same trend was observed for sodium, zinc and iron respectively. While calcium was not detected in the control sample (100\% maize), the result obtained indicated that there was no significant difference in the calcium content among the flour blends. Addition of cowpea into maize was observed to increase the mineral contents of the flour blends. This is in agreement with the observation made by Chikwendu (2007) in the study of the chemical composition of Akara produced from ground bean and maize blends.

The total viable count of the flour blends was found to range from 3.8 to $4.7 \times 10^{3} \mathrm{cfu} / \mathrm{ml}$ with the highest value recorded for $100 \%$ maize flour and the lowest value recorded for $10 \%$ cowpea substitution, with exception of this sample, there was no significant difference in the total viable count of the control sample and the flour blends. However, significant difference $(p \leq 0.05)$ was observed in the result obtained for the yeast and mould count which ranged between 2.2 to $3.17 \times 10^{3} \mathrm{sfu} / \mathrm{ml}$, the least value was recorded for $100 \%$ Maize flour while the sample with $30 \%$ cowpea substitution has the highest. No coliform was detected in any of the samples, an indication that the samples were completely free from faecal contamination. These findings were in agreement with the trend observed by Otunola et al. (2012). 


\section{Conclusion}

This study has shown that increasing the percentage of cowpea flour in maize and cowpea flour blends improved the protein and mineral contents of the maize; this indicates a higher nutrient value with respect to protein and mineral contents. The functional properties (water and oil absorption, foaming capacity, emulsion capacity and stability) of the maize flour were also enhanced with the addition of cowpea as the blends had higher values compared to $100 \%$ maize flour. Microbiological qualities were not significantly affected by cowpea enrichment. Conclusively, cowpea can be added to maize to produce a composite flour of high nutritive and enhanced functional properties.

\section{CONFLICT OF INTEREST}

The authors declare that they have no conflict of interest.

\section{REFERENCES}

AACC. (2000). Approved Methods of the American Association of Cereal Chemists (10th ed). St. Paul, M. N.

Afoakwa, E. O. (1996). Storage Characteristics and Quality Evaluation of Cowpea Fortified Traditional Foods. B.Sc. Dissertation, Department of Nutrition and Food Science, University of Ghana, Legon, Ghana, unpublished data.

AOAC. (1990). Official Methods of Analyses (15 $5^{\text {th }}$ Ed.) Association of Official Analytical Chemists, Washington D.C.

Barber, L. F., Bebeya, E., Eke Ejiofor, J., \& Owuno, F. (2010). Effect of Cowpea Supplementation on the Physico-Chemical and Sensory characteristic of "Epiti" a steamed maize and plantain pudding. Journal of Nigeria Food 28 (2), 448-453.

Chikwendu, N. J. (2007). Chemical composition of "AKARA" (Fried groundbean paste) Developed from Fermented and Germinated Groundbean (Kerstingiella georcarpa) and Maize (Zea mays) Blends. Journal of Agriculture, Food, Environment and Extension, 6(1)1-7.

Coffman, C., \& Garcia, V. V. (1977). Functional properties of the Protein Isolate from many Flour. Journal of Food Technology, 12, 473-484.

Collins, C. H., Lyne, M., \& Grage, J. M. (1989). Microbiological Methods (6th Edn), Butter North and Co. Ltd., Pp. 122-135.

David, M. O. (2006). Nigeria N0. 1 Market for U. S. Wheat Potential for Other Grains and Feeds USAID Foreign Agriculture Service Bulletin, Pp. 1-2.

Deshpande, S. S., Sathe, S.K., Corforth, D., \& Salunkhe, D. K (1983). Effects of Dehulling on Functional Properties of Dry Bean (Phaseolus vulgaris L.) Flour. Cereal Chemistry, 396401

Etsey, A. N., Sakyl-Dawson, E., Sefa-Dedeh, S. Afoakwa, E. O.,Tano-Debrah, K., \& Annor, G. A. (2007). Effects of Cowpea Fortification and Level of Ripeness of Plantain on the Nutritive Value of Plantain Based Snacks Foods. African Journal of Biotechnology, 6(6), 799-802

FAO (1992). Food and Agricultural Organization. Maize in Human Nutrition, UN Rome.
FAO (2010). Food and Agriculture Organization of the United Nations. Irrigated corn for Grain, Harvested Acres. Retrieved 5 November, 2010.

Ihekoronye, A. I., \& Ngoddy, P.O. (1985). Integrated Food Science and Technology for the Tropics. Macmillan Publisher Limited, London, Pp. 241-289.

IITA. (2009). Cowpea Crop - IITA (International Institute of Tropical Agriculture (IITA).

Maize encyclopedia (2013). Cereal Grain: In British English "Corn" means any cereal. From Wikipedia, the free encyclopedia https://en.wikipedia.org/wikiMaize

Masumateu, A. (1972). Whipping and Emulsifying Properties of Soybean Products Agric. Bio Chem. 36, 719-727.

Meyers, J. W., John, B., George, M. T., \& Francisco, O. (1997). World Society and the Nation State. American Journal of Sociology, 103(1), 144-181.

Odedeji, J. O., \& Oyeleke, W. A. (2011). Proximate, Physicochemical and Organoleptic Properties of Whole and Dehulled Cowpea Seed Flour (Vigna unguiculata) Pakistan Journal of Nutrition, 10(12) 1175-1178.

Okaka, J. C., \& Potter, N. N. (1977). Sensory, Nutritional and Storage Properties of Cowpea Powders Processed to Reduce Beany Flavor. J. Food Sci. 44, 1539-1542.

Olugbani, L., Oke, L. O., \& Ogunsua, A. O. (2002). Mineral Content of Agricultural Products, 1st Edition, Macmillan Press Ibadan, Nigeria p. 91.

Omueti, O., Morton, I. D., \& Emery, P. W. (1992). Nutritional characteristics of soybean seed flour after processing with sodium bicarbonate or trona. Int. J. Food Sci. Nutri., 43, 147153.

Osundahunsi, O. F., \& Aworh, O. C., (2003): Nutritional evaluation, with emphasis on protein quality of maize-based complementary foods enriched with soya bean and cowpea tempe. International Journal of Food Sc. and Tech., 38, 809 813

Otunola, E. T., Sunny-Roberts, E. O., Adejuyitan, J. A., \& Famakinwa, A.O. (2012): Effects of Addition of Partially Defatted Groundnut Paste on Some Properties of "Kokoro" (a Popular Snack made from maize Paste). Agriculture and Biology Journal of North America, 3(7), 280-286.

Sathe, S. K., Desphande, S. S., \& Salunke, D. K. (1982). Functional Properties of Lupin Seed (Lipnusmutabilis) Protein and Protein Concentrates. Journal of Food Sciences, 47, 491-497.

Sefa-Dedeh, S., Kluvitse, Y., \& Afoakwa, E. O. (2001). Influence of Fermentation and Cowpea Steaming on Some Quality Characteristics of Maize-Cowpea Blends. African Journal of Science and Technology (AJST) Science and Engineering Series, 2, 71-80.

Singh, B. B., Mohan-Raj, D. R., Dashiel, K. E., \& Jackai L.E.N. (1997). Advances in Cowpea Research Post Harvest Storage of Cowpea in sub-Saharan Africa. IITA/JRCA Publication IITA Ibadan, Nigeria IP, 302-312

Ukpabi, U. J., \& Ndimele, C. (1990). Evaluation of Gari Production in Imo State, Nigeria. Nigeria Food Journal, 8,105 $-110$. 